\title{
Effect of Probiotic Giving on Digestive Function in Patients Post-Perforated Colorectal Cancer surgery
}

\author{
Impol Hutapea, Ida Bagus B.S.A, Untung Alfianto, \\ Masters Program in Family Medicine, Sebelas Maret University
}

\begin{abstract}
Background: One of the goals of colorectal cancer surgery is to facilitate the digestive tract to function properly. Surgery performed can lead new problems such as infection, sepsis, postoperative pain, and nausea vomiting. Modulation of perioperative nutrition of intestinal microbiota such as probiotics is more and more applied as a strategy to reduce complications of elective surgical infection and accelerate the improvement of gastrointestinal symptoms such as flatus and defecation. The purpose of this study was to analyze the effect of giving probiotics on digestive function in patients after colorectal cancer surgery.

Subjects and Methods: The subjects of this study were postoperative patients with colorectal cancer, with a total sample of 20. The sampling technique used non-random sampling. This type of the study is quasi experimental design with Post-test Only Control Design method. In this design, the sample is divided into two groups namely, group I was given probiotics and group II was not given probiotics then the follow up treatmen was conducted to assess the effect on the digestive function of patients after colorectal cancer surgery.

Results: The majority of post-operative colorectal cancer patients were $>50$ years $(85 \%)$. The sex of post operative patients with colorectal cancer balanced between men and women, which was equally 50\%. There was a significant difference between intestinal bowel surgery after colorectal cancer surgery which was given probiotics with no probiotics given $(\mathrm{p}<0.05)$. Similarly, post operative flatus colorectal cancer patients also had significant differences with the values ( $\mathrm{p}<0.05)$. As for the defecation patients of post-surgery colorectal cancer, there was also a significant difference between the defecation patients of post-surgery of colorectal cancer surgery given probiotics and those not given probiotics with values $(\mathrm{p}<0.05)$.

Conclusion: statistically, there was an effect of giving probiotics to digestive function including bowel sound, flatus, and defecation of post-surgery patient of colorectal cancer.
\end{abstract}

Keywords: Probiotics, digestive function, colorectal cancer

\section{Korespondensi:}

Impol Hutapea. Masters Program in Family Medicine, Sebelas Maret University. Email: papihamora@gmail.com

\section{BACKGROUND}

$\overline{\text { Despite advances in molecular characteris- }}$ tics, screening, diagnosis, surgical techniques, and chemotherapy in the last few decades, colorectal cancer (CRC) is still one of the health problems in the USA. In 2010, it was estimated that there were 142,750 cases of CRCs in the United States (Haddad, 2011). It is approximately 60\% of cases which occur in developed countries despite significant increases in incidence in developing countries including Indonesia, where colorectal cancer is ranked 3 after other types of cancer (Ferlay et al., 2010).

Surgery is one of the treatment on colorectal cancer handling. One of the goals of surgery is to facilitate the digestive tract to function properly (American Cancer Society, 2013). Surgery can lead to new problems such as infection, sepsis, postoperative pain, and nausea vomiting (Harijanto, 2010; Abdullah, 2012).

Modulation of perioperative nutrition of the intestinal microbiota is more and 
more applied as a strategy to reduce complications of elective surgical infections and accelerate the gastrointestinal symptoms recovery such as flatus and defecation (Abdullah, 2012). Probiotics are living organisms capable of providing beneficial effects on the host's health when consumed in sufficient quantities (FAO / WHO, 2001; FAO / WHO, 2002; ISAPP, 2009) by improving intestinal microflora balance upon entry in the gastrointestinal tract (Shitandi et al ., 2007; Dommels et al., 2009; Weichselbaum, 2009).

Adhesion of probiotic bacteria to specific sites of intestinal mucosal cells is also one of the action of competition with pathogens (Adlerberth et al 1996) Proteins that play a role in the probiotic bacterial adhesion process are present on the surface of bacterial cells, this is related to the important role of bacterial interactions with the environment his life (Tanskanen et al 2002). Adhesion is a prerequisite of colonization, antagonistic activity against enteropathogens, immune system regulation, and to repair damaged intestinal mucosa (Surono, 2004).

Research conducted by Lee et al. (2014) using a randomized clinical trial (RCT) technique, that patients with colorectal cancer who completed treatment at least 6 weeks before the initiation of probiotics. After recovering from surgery or postoperative chemotherapy, patients who received probiotics for 12 weeks had increased bowel symptoms and increased quality of life related to cancer.

Consumption of probiotics is usually applied to the manufacture of processed food products such as; yogurt, cheese, refreshments, ice cream, yakult, frozen candies and yogurt (Senok, 2009; Granato et al., 2010). The minimum number of probiotic strains present in food products is $106 \mathrm{CFU} / \mathrm{g}$ or the number of probiotic strains to be consumed daily about 108 $\mathrm{CFU} / \mathrm{g}$, in order to compensate for the possibility of decreasing the amount of probiotic bacteria while on the digestive tract (Shah, 2007) .

In RSDM quite a lot obtained and done in the form of surgery treatment of colorectal cancer cases. Probiotics itself has not been used routinely and there is no writing about the use of this probiotic itself.

Based on the background, so it is necessary to do research about the effect of giving probiotics to digestion function in patients after colorectal cancer surgery in RSDM.

\section{SUBJECTS AND METHOD}

\section{Study design}

This research used quasi experimental design with Post-test-Only Control Design method. In this study, the sample was divided into two groups namely, group I was given probiotics and group II was not given probiotics and then follow-up is conducted to assess the effect on the digestive function of patients after colorectal cancer surgery. The study was conducted in RSUD dr. Moewardi, Surakarta in March until august 2017.

\section{Study instrument}

The instrument used in this study was an observation sheet to know the digestive function. The population in this study were post-operative patients with colorectal cancer. Sampling technique with non random sampling was applied in this study, with the following criteria:

a) Inclusion criteria

(1) Patient/family who agreed to participate in the study and sign the approval letter.

(2)Colorectal cancer Patients taking surgery resection and anastomose surgery.

(3) Age: 18 - 60 years old. 
b) Exclusion criteria:

(1) Patients with immunologic and malnutrition disorders.

(2) Patients suffer anastomose complications

(3) Resigned as research subject

\section{Data Analysis}

The statistical test used in this study is Mann Whitney which is to compare between 2 sample groups. This technique is used to compare two measurable variables of categorical scale (nominal or ordinal)

(Dahlan, 2013).

\begin{tabular}{l}
\hline RESULTS \\
\hline 1. Univariate analysis results \\
a. Characteristics of study subjects \\
Characteristics of study subjects were \\
categorized which was the majority age over \\
50 years old ( $85 \%)$. The gender of post- \\
operative colorectal cancer patients was \\
balanced between men and women, which \\
was equally $50 \%$.
\end{tabular}

Table 1. Characteristics of study subjects by age

\begin{tabular}{lll}
\hline Charactersitics & Frequency & \% \\
\hline Age & & \\
$<5$ o years old & 3 & 15 \\
$\geq 50$ years old & 17 & 85 \\
Sex & & 50 \\
Man & 10 & 50 \\
Women & 10 & \\
\hline
\end{tabular}

b. Descriptive Bowel of post-surgery patients with colorectal cancer

Table 2 showed that post-surgery patients with colorectal cancer who were not given

Table 2. Descriptive description of bowel of postoperative patients with colorectal cancer

\begin{tabular}{lccc}
\hline \multicolumn{1}{c}{ Bowel } & Probiotic & Non Probiotic & Total \\
\hline Normal & 10 & 5 & 15 \\
Less & 0 & 5 & 5 \\
\hline
\end{tabular}

probiotics had poor bowel of 50\%, whereas the probiotics group had 100\% normal bowel and did not increase.

\section{c. Descriptive descriptions of flatus post-colorectal patients cancer surgery}

Flatus post-surgery patients with colorectal cancer given probiotics tend to be better

\begin{tabular}{llll}
\hline Flatus & Probiotic & Non Probiotic & Total \\
\hline Normal & 10 & 5 & 15 \\
Increase & 0 & 5 & 5 \\
\hline
\end{tabular}

d. Descriptive descriptions of defecation patient of post-colorectal cancer According to Table 4, deficiency of patients of post-surgery with colorectal cancer given probiotics is all normal defected. However, than those not given probiotics with the score $50 \%$ who suffered poor flatus. Flatus is good if flatus is normal frequency with 10 -20 times/day.

Table 3. Descriptive description of patients with post-operative colorectal cancer

post-surgery colorectal patients who were not given probiotics from 10 subjects, 6 of them were having diarrhea and the other 2 patiens had constipation. 
Table 4. Descriptive defecation of post-operative patients with colorectal cancer

\begin{tabular}{llll}
\hline Defekasi & Probiotic & Non Probiotic & Total \\
\hline Diarrhea & 0 & 6 & 6 \\
Normal & 10 & 2 & 12 \\
Constipation & 0 & 2 & 2 \\
\hline
\end{tabular}

\section{The result of bivariate analysis}

Different test results were to compare between the effectiveness of the treatment and the post-surgery patients with colorectal cancer given probiotics and those not given probiotics. The different test applied was the Mann Whitney analysis test.

a. Differential test of colon cancer patients post-colorectal cancer operations between groups given probiotics and those not given probiotics.

Different test results of intestinal carcinoma of postoperative patients of

Table 5. Different test results of intestinal carcinoma of patients after colorectal cancer surgery

\begin{tabular}{lllrrrr}
\hline \multicolumn{1}{c}{ Group } & Mean Rank & U & W & Z & p \\
\hline Probiotic & 8 & 25,000 & \multirow{2}{*}{80,000} & \multirow{2}{*}{$-2,517$} & \multirow{2}{*}{0.012} \\
Non Probiotic & 13 & 25, \\
\hline
\end{tabular}

b. Different flatus test of post-operative patients of colorectal cancer between groups treated with probiotics and those not given probiotics Table 6 shows that there are significant differences in postoperative colorectal patients' postoperative studies given pro-

Table 6. Different flatus test results of postoperative patients with colorectal cancer

\begin{tabular}{lllllll}
\hline \multicolumn{1}{c}{ Group } & Mean Rank & U & W & Z & p \\
\hline Probiotic & 8 & 25,000 & 80,000 & $-2,517$ & \multirow{2}{*}{0.012} \\
Non Probiotic & 13 & 2 & \\
\hline
\end{tabular}

c. Differential Test of Patient Defecation After Colorectal Cancer Operation between probiotic and nonprobiotic-treated groups

When viewed from the mean rank value in the probiotic group the average rank is 6.50 lower than the non-probiotic group's colorectal cancer between groups who were given probiotics and not given probiotics showed no significant differences in intestinal bowel patient postoperative colorectal cancer between groups who were given probiotics and not given probiotics. When viewed from the mean rank values are also seen, given the probiotic value is smaller than that given the probiotic difference 5. This result explains that the provision of probiotics affect bowel sounds of patients after colorectal cancer surgery.

biotics to those not given probiotics. These results are similar to the results of different test of bowel sounds with the same mean rank values. In conclusion that administration of probiotics other than bowel sounds, also affects the quality of postoperative flatus colorectal cancer patients. (1) average ranking of 14.50 , the difference of 8. The results showed that there was a significant difference between postoperative defect of colorectal cancer patients and those given probiotics and who are not given probiotics. 
Hutapea et al./ Effect of Probiotic Giving on Digestive Function

Table 7. Differential test results of post-operative colorectal cancer defect patients

\begin{tabular}{llrrrr}
\hline \multicolumn{1}{c}{ Group } & \multicolumn{1}{c}{ Mean Rank } & U & W & Z & p \\
\hline Probiotic & 6.50 & \multirow{2}{*}{10,000} & 65,000 & $-3,559$ & \multirow{2}{*}{$<0.001$} \\
Non Probiotic & 14.50 & & &
\end{tabular}

\section{DISCUSSION}

Colon and rectum are part of the colon in the digestive system called the gastrointestinal tract. The function of the colon is to assist the body absorbing nutrients and fluids from foods and drink. After absorbing the nutrients needed, the intestines then remove substances that are not useful in the body in the form of feces through the rectum and anus (Tortora and Grabow, 2002). Colorectal cancer occurs when a tumor is formed in the lining of the colon (National Institute of Health, 2013).

Surgery is the treatment for colorectal cancer. One of the goals of surgery is to facilitate the digestive tract in order to function properly (American Cancer Society, 2013). After the dysfunction colorectal surgery of the intestinal activity, it suffered disruption typically from its normal. The first activity occurs in the gut that is recorded usually less than the first 24 hours. From the first 6-12 hours, there is restoration of bowel motility, 12-24 hours in the stomach and 48-72 hours in the colon. Bowel peristalsis and flatus exposure are typical signs from returning this function, and feces have usually been removed in 1-2 days (Siegel, 2011).

Characteristics of post-operative patients with colorectal cancer were based on range of the age from 20 research subjects with the majority of respondents over 50 years (85\%). According to Alteri (2011), young adulthood can suffer colorectal cancer, but it could increase over 50 years old, about 9 out of 10 people were diagnosed with colorectal carcinoma in 50 years old minimum.
If we consider from the gender of the colorectal cancer in this study was balanced between male and female sex which was $50 \%$. These results are in the same line as De Jong's (2005) theory. It is said that the case of colon cancer in Indonesia is quite high, as well as with the mortality rate. Both men and women were balanced to have rectosigmoid which was around $75 \%$.

\section{Effect of probiotics on bowel of post-surgery colorectal cancer patients}

Bowel sounds are sounds caused by the sound of air and fluid in the intestine because of the intestinal peristalsis. This sound is heard through a stethoscope in the entire abdominal quadrant. Bowel sounds was with normal values of 5-35 x / min. one of the way to treat the post-surgery colorectal cancer patients was by monitoring bowel sounds and degrees of abdominal distension. Manipulation of intestinal surgery stops peristalsis and causes ileus. The intestinal bowel and pasus flatus were the indications of peristaltic (Lewis and Heitkemper, 2000). Probiotics are one of alternatives to assist the gastro intestinal recovery after surgery (Abdullah, 2012).

The results of this study indicated that, intestinal bowel of post-surgery patients with colorectal cancer that is not given probiotics suffer from poor bowel sound as many as 50\%, whereas the one given probiotics had 100\% normal bowel sounds and did not increase.

Adhesion is a prerequisite of colonization, antagonistic activity against enteropathogens, immune system regulation, and 
repair damaged intestinal mucosa so that digestive function becomes better (Surono, 2004).

Different test results of intestinal carcinoma of post-surgery patients of colorectal cancer between groups who were given probiotics and not given probiotics showed that there were no significant differences in intestinal bowel patient's post-surgery colorectal cancer between groups who were given probiotics and not given probiotics. We can see from the mean values also, the prebiotic group's result was smaller than that the nonprobiotik which was 5 . This result indicated that the probiotics group affects bowel sounds of patients of post-surgery colorectal cancer.

The study conducted by Lee et al. (2014) implemented randomized clinical trial (RCT) showed that patients with colorectal cancer who completed treatment at least 6 weeks before the initiation of probiotics. After recovering from surgery or post-surgery chemotherapy, patients who received probiotics for 12 weeks had increased bowel symptoms and increased quality of life related to cancer.

\section{Effect of Probiotics on Flatus Patients Post-Colorectal Cancer Radiation}

The results of this study indicated that flatus patients post-surgery colorectal cancer given probiotics tend to be better than those not given probiotics with the score $50 \%$ suffered poor flatus. Modulation of perioperative nutrition of intestinal microbiota is more and more applied as a strategy to reduce complications of elective surgical infections and accelerate the gastro intestinal symptoms recovery such as flatus and defecation (FAO / WHO, 2001; FAO/WHO, 2002; ISAPP, 2009), by improving equilibrium intestinal microflora upon entering the digestive tract (Shitandi et al., 2007; Dommels et al., 2009; Weichselbaum, 2009). It can be detected if the digestive system run normal after colon cancer surgery was the stomach was not flatulence so that it was not often flatus. Flatus is normal if the frequency is $10-20$ times/day.

There was a significant difference in postsurgery colorectal patients' between probiotics and non- probiotics given. Probiotic compounds can clean the digestive tract and mucosa where they live. Therefore, it can overcome disorders of the digestive tract that is not running properly for example flatulence and flatus often. In addition, it also produces vitamins $\mathrm{B}_{3}, \mathrm{~B}_{5}$, B6, B9, and B12 (Parves et al., 2009).

\section{Effect of Probiotics on Patient Defecation Post-Colorectal Cancer Surgery}

Colon and rectal cancers caused changes the defecation pattern such as constipation, diarrhea and abdominal discomfort often flatus (De Jong, 2005). Giving probiotics are considered to overcome problems related to the digestive tract after the operation of colorectal cancer. The results of the study indicated that the pattern of post-surgery defecation of patients with colorectal cancer given probiotics all normally defecated. However, post-surgery colorectal patients who were not given probiotics from 10 subjects, 6 of them were having diarrhea and the other 2 patiens had constipation. Several studies showed that probiotics can increase nutrient absorption. Probiotics have been widely used for the prevention of diarrhea and constipation (Salazar et al., 2007; Pant et al., 2007; Tabbers and Benninga, 2007; Collado et al., 2009)

As we can see from the mean value in the probiotic group whic was 6.50 was lower than the nonbiotic group rank with the average score 14.50 , and the difference 
was 8 . The test results showed that there was a significant difference between defecation patients of post-surgery of colorectal cancer given probiotics and not given probiotics.

Based on the results of a study conducted by Brown and Valiere (2004), there is a correlation between probiotic use and improvement of clinical symptoms such as diarrhea, irritable bowel syndrome, inflammatory bowel disease, cancer, depressed immune system, hyperlipidemia and liver. Despite of diarrhea, other digestive disorders that might appear from colorectal cancer is constipation. Probiotics are useful for maintaining a balance of intestinal flora. A balanced intestinal flora prevents the constipation. Lactic acid bacteria can increase intestinal peristalsis so it might be able to overcome constipation (Oberoi et al., 2007; Weichselbaum, 2009). The results conducted by Setyani (2012), it said that there was a significant difference in the pattern of defecation elimination between groups given probiotics and not given probiotics, meaning that there was an effect on probiotic drink on the regularly defecation elimination pattern in infarct myocard patients.

Based on the results of this study, it can be concluded that there was a significant difference between intestinal bowel patients of post-surgery colorectal cancer given probiotics and not given probiotics. There was a significant difference between the flatus patients of post-surgery colorectal cancer given probiotics and those not given probiotics. There was a significant difference between the defecation patients of post-surgery colorectal cancer patients given probiotics and those not given probiotics.

\begin{tabular}{l}
\hline REFERENCE \\
\hline Adlerberth I, Ahrne S, Johansson ML, \\
Molin G, et al., (1996). A Mannose- \\
Specific Adherence Mechanisme in \\
Lactobacillus plantarum Conferring \\
Binding to Human Colonic Cell Line \\
HT-29. Journal of Applied and \\
environmental Microbiology. 62(7): \\
2244-2251
\end{tabular}

Alagozlu H, Karakan T (2012). Probiotics are Sensitive Microorganisms: Lactobacillus Can be Affected by Stomach Acid, Antibiotic, and Bowel Cleansing. Dig Dis Sci. 57: 2477-8.

Alteri R, Bandi P, Brooks D, Cokkinides V, Doroshenk M, Gansler T, et al (2011). Colorectal Cancer Facts \& Figure 2011-2013. Atlanta: American Cancer Society.

American Cancer Society (2014). Colorectal Cancer. Atlanta: American Cancer Society.

American Joint Commitee on Cancer (AJCC) (2010). Colon and Rectum Cancer Staging. 7th Edition. SpringerVerlag New York: American Cancer Society.

Bengmark S, Lorenzo G, Culebras JM (2001). Use of Pro-, Pre- and Synbiotics in the ICU: Future Options. Nutr Hosp. 16(6):239-256

Boyle RJ, Robins-Browne RM, Tang MLK (2006). Probiotic use in clinical practice: what are the risk?. Am J Clin Nutr. 83:1256-1264

Kvasnovsky CL (2015). What colorectal surgeons should know about probiotics: a Review. Colorectal Disease a 2015. The Association of Coloproctology of Great Britain and Ireland. 17, 840-848. doi:10.1111/codi.13046

Coconnier MH, Bernet MF, Chauviere G (1993). Adhering Heat-Killed Human Lactobacillus Acidophilus, Strain LB, Inhibits the Process of Pathogenicity 
of Diarrhoeagenic Bacteria in Cultured Human Intestinal Cells. J Diarrhoeal Dis Res. 11(4): 235-242.

Collado MC, Isolauri E, Salmien S, Sanz Y (2009). The impact of probiotic on gut health. Curr Drug Metab. 10(1): 68-78.

Dahlan MS (2013). Statistik Untuk Kedokteran dan Kesehatan. Jakarta: Salemba Medika.

De Jong W (2005). Buku Ajar Ilmu Bedah. Jakarta: EGC.

Djunaedi D (2007). Pengaruh Probiotik Pada Respon Imun. Jurnal Kedokteran Brawijaya, 23(1).

FAO/WHO (2001). Joint FAO/WHO Expert Consultation on Evaluation of Health and Nutritional Properties of Probiotics in Food Including Powder Milk with Live Lactic Acid Bacteria. Amerian Córdoba Park Hotel, Córdoba, Argentina. (2002). Joint FAO/WHO Working Group Report on Drafting Guidelines for the Evaluation of Probiotics in Food. London.

Ferlay J, Shin HR, Bray F, Forman D, Mathers C, Parkin DM (2010). GLOBOCAN 2008 v2.0, Cancer Incidence and Mortality Worldwide: IARC Cancer Base. No. 10 [Internet]. Lyon, France: International Agency for Research on Cancer; 2010. Available from: http://globocan.iarc.fr.

Fooks LJ, Gibson GR (2002). Probiotics as Modulators of the Gut Flora. Br J Nutr. 88-Suppl 1:S39-49.

Fuller R (1991). Probiotics in Human Medicine. Gut. 32:439-442.

Granato D, Branco GF, Cruz AG, Faria JDAF, Shah NP (2010). Probiotic Dairy Products as Functional Foods. Comprehensive Reviews in Food Science and Food Safety 9:455-470.
Hurlock EB (2012). Psikologi Perkembangan Suatu Pendekatan Rentang Kehidupan. Jakarta: Erlangga.

Johns Hopkins Medicine Colon Cancer Centre. (2015). Colorectal Cancer Overview. Available from: http://www.hopkinscoloncancercenter.org/ CMS/CMS_Page.aspx?CurrentUDV= 59\&CMS_Page_ID=D291D721-32CD4CD7-B607-3B5B3BC2893C.

Katelaris PH. (1996). Probiotic Control of Diarrhoeal Disease. Asia Pacific J Clin Nutr. 5:39-43.

Lee JY, Chu SH, Jeon JY, et al (2014). Effects of 12 Weeks of Probiotic Supplementation on Quality of Life in Colorectal Cancer Survivors: a Double-Blind, Randomized, PlaceboControlled Trial. Dig Liver Dis. 46: 1126-32.

Lewis SM, Heitkemper MM (2000). Medical Surgical Nursing: Assesment \& Management of Clinical Problems. Ed.5. St.Louis: Mosby.

Liu Z, Li C, Huang M, Tong C, Zhang X, Wang L, et al (2015). Positive regulatory eff ects of perioperative probiotic treatment on postoperative liver complications after colorectal liver metastases surgery: A doublecenter and double-blind randomized clinical trial. Journal BMC Gastroenterol. 15: 34. doi: 10.1186/s12876015-0260-z.

McFarland L, Elmer GM (2005). Probiotics in Food Safety and Human Health. New York: Marcel Dekker, Inc.

Obreoi A, Aggarwal A, Singh N (2007). Probiotic in Health a Bug For What is Bugging You, Review Artikel Departements of Microbiology and Medicine, 9(3): 116-119. http://www.jkscience.org.

Pant N, Marcotte H, Brüssow, Svensson L, Hammarström L (2007). Effective 
Prophylaxis Against Rotavirus Diarrhea Using a Combination of Lactobacillus rhamnosus GG and Antibodies. BMC Microbiol. 7(86): $2180-2187$.

Parvez S, Malik KA, Kang SA, Kim HY. (2006). Probiotics and their fermented food products are beneficial for health. Journal of Applied Microbiology. 100: 1171-1185.

Prado FC, Parada JL, Pandey A, Soccol CR (2008). Trends in non-dairy probiotic beverages. Food Res. Int. 41:111-123

Sjamsuhidajat \& De jong. (2011). Buku Ajar Ilmu Bedah. Jakarta: EGC.

Surono, IS. (2004). Probiotik Susu Fermentasi dan Kesehatan. Jakarta: PT. Tri Cipta Karya.
Tabbers MM, Benninga MA (2007). Administration of Probiotic Lactobacilli to Children With Gastrointestinal Problems: There is Still Little Evidence. Ned. Tijdschr. Geneeskd. 151(40): $2198-2202$.

Tortora GJ, Derrickson BH (2009). Principles of Anatomy and Physiology. Twelfth Edition. Asia: Wiley.

Widiyaningsih EN (2011). Peran Probiotik untuk Kesehatan. Jurnal Kesehatan, ISSN 1979-7621, 4(1): 14-20.

WHO (2004). The World Health Organization Quality of Life (WHOQOL)BREF. WHO Indonesia. 